Máté J. Julesz, Ph.D., Scientific Researcher

University of Szeged

Medical Faculty

Insitute for Forensic Medicine

mate.julesz@freemail.hu

\title{
TENDENCIES IN MEDICAL NEGLIGENCE, WITH SPECIAL REFERENCE TO HUNGARY
}

\begin{abstract}
Medical negligence has long been in the focus of legal research in most countries. In some countries, the negligence standard has been replaced by the avoidability standard, the latter leading to a no-fault system. Nonetheless, most legal systems apply the negligence standard. In my opinion, the negligence standard should be sustained because, despite the undoubted advantages of the no-fault system, the 'good old law' on medical negligence promotes greater legal certainty and patient safety. Criminal medical negligence differs from civil medical negligence as regards onus, as well as in other ways. In the UK, many lawyers and physicians have protested against the legal practice of gross negligence manslaughter, an effort which may also serve as an example for other countries. In most continental European countries, the enforcement of a foreign punitive damages judgment would run counter to the ordre public; however, in some countries, such as in France and Hungary, a punitive damages judgment might be enforced.
\end{abstract}

Keywords: civil medical negligence, Hungary, punitive damages, compensatory damages, defensive medicine, criminal medical negligence, the right to a cheap judicial procedure.

\section{HISTORICAL BACKGROUND}

The type of medical negligence cases we know today first emerged in the nineteenth century all over the developed world. Of course, there were countries, such as the USA, where a reliable case law had developed in this area by the midnineteenth century. In other countries, such as Canada, medical negligence cases first appeared at the end of the nineteenth century. In Europe, the beginning of 
medical negligence case law dates back to the second half of the nineteenth century. Brown writes as follows: 'As the number of doctors increased in Canada, some physicians may have encouraged negligence suits against their competitors.' This might have been an important factor in Europe as well.

Medical negligence cases could seriously damage the reputation of physicians. Therefore, physicians opposed the development of medical negligence case law. In the end, the reluctance of physicians could not stop lawyers and unsatisfied patients from bringing physicians to court. The nineteenth century marked the beginning of the long-lasting development of medical negligence case law and legislation. Usually, legislation on medical negligence has followed case law and not the reverse. There were also medical malpractice cases before the nineteenth century, but they had little to do with present-day' medical malpractice case law.

\section{THE NEW TENDENCY TOWARD DEFENSIVE MEDICINE}

As Berlin wrote in 2017, in the USA, lawsuits against medical practitioners were, in the beginning, based on errors of commission (i.e., the physician did something wrong, such as prescribing the wrong drugs), which were, from the midtwentieth century, replaced by errors of omission (i.e., the physician failed to do something, such as making a proper diagnosis). ${ }^{2}$ This led to present-day' defensive medicine, and not only in the USA. Defensive medicine has changed medical and legal practice a great deal in all countries. Nowadays, medical experts, as well as lawyers, focus on whether there was an error of omission or not. This case law has led to many expensive and futile medical examinations to protect healthcare providers. The consideration of errors of omission cannot be rejected outright because medical negligence may be caused by an error of omission, and an omission might lead to more serious consequences than, in some cases, an error of commission. However, a just equilibrium is to be sustained to address the real problem. If an error of omission results in serious health consequences, it seems normal to establish civil law liability and, if necessary, criminal law liability as well. It is only partly the act of the author of the damage that counts; the consequences affecting the patient also play an important role when establishing the healthcare provider's liability. Thus, a missing diagnosis that would otherwise have saved the life or health of the patient might be detrimental to the patient, and the healthcare provider's liability should be established when really necessary. The only point is that the case law should not push medical negligence cases to-

${ }^{1}$ R.B. Brown, Canada's first malpractice crisis: medical negligence in the late nineteenth century, Osgoode Hall Law Journal, 3/2017, 777-804.

${ }^{2}$ L. Berlin, Medical errors, malpractice, and defensive medicine: an ill-fated triad, Diagnosis, 3/2017, 133-139. 
wards an absolute liability that would not leave room for exculpation of the doctor. Objective liability, when giving the healthcare provider a real opportunity of exculpation, might be accepted on condition that it is not the healthcare provider who ultimately covers the damages, but the state budget. In most European countries, objective liability is reserved to counterbalance a high risk imposed on the injured party by a dangerous activity.

Healthcare providers should be protected by legislative measures; however, the social attitude towards them also counts. In market democracies, legislative measures are initiated by legislators elected by members of the society. The more people have the right to vote, the more legitimacy is granted to legislative measures. The social attitude towards physicians and nurses is reflected by a certain need for the objectivation of medical negligence. Patients expect more attention and a higher level of healthcare for their money, which leads to high level requirements. From time to time, these high level requirements emerge in case law. Nevertheless, legislators should not place a greater burden on healthcare providers by objectivating their liability because that is where defensive medicine stems from.

\section{THE EMERGING NEED FOR PUNITIVE DAMAGES}

The Hungarian Civil Code, which came into effect on 15th January 2014, introduced the legal institution of punitive damages into Hungarian civil law. In practice, this means that after an assessment of economic damages, non-economic damages are also assessed and this latter sort of damages may be augmented by a punitive factor. Non-economic damages can be augmented according to the level of culpability of the author of the damage, the severity and repetitiveness of the damaging act, and the effect of the damaging act on both the injured party and relatives.

This sort of punitive damages differs greatly from punitive damages applied in the UK and in the USA. In those countries, compensatory damages are assessed first: i.e., the economic and non-economic damages. Then, the judge may impose punitive damages on the author of the damage according to the level of culpability of that party. Since, in most continental European countries, punishment under civil law runs counter to the ordre public, when it comes to enforcement of a USA judgment. For example, in Germany, a request to enforce compensatory damages is accepted, while a request to enforce punitive damages is rejected. In Hungary, both sorts of damages may be enforced. However, this is a new phenomenon in Hungary, with little case law. Hungarian courts are still keen on delimiting the application of non-economic damages combined with punitive damages. The problem of the enforcement of judgments on punitive damages in Europe gives rise to various solutions in the jurisprudence of various European 
countries. When it came to enforcing a judgment in France on punitive damages awarded in Schlenzka \& Langhorne versus Fountaine Pajot S.A. case in the USA, the French Cour de Cassation found that merely the legal institution of punitive damages was not contrary to the French ordre public but the punitive damages should not be disproportionate. ${ }^{3}$ This way of legal thinking on punitive damages is a possible solution to the dilemma of whether to enforce punitive damages in continental Europe or not. Nevertheless, it remains a judicial problem to decide when punitive damages awarded in the USA should be considered as not disproportionate, and thus as enforceable. Legal certainty largely depends on the predictability of the judicial outcome. Calandrillo argued that 'the Supreme Court must drastically revise its approach to punitive damages jurisprudence: such awards should not be arbitrarily based on a gut reaction to how reprehensibly we feel a defendant acted.' ${ }^{4}$

In Hungary, sub judice, the claimant does not have to assess the amount of the non-economic damage suffered. The mere breach of the person's right (e.g. the right to health, privacy, reputation, non-discrimination and/or data protection) leaves room for non-economic damages augmented by a punitive factor. In Hungary, it is only economic damage that is to be expressed in a pecuniary way. This gives freedom to the judge when it comes to assessing non-economic damages, although, this liberty should be limited by case law. Case law orientates judges with a non-legislated tariff that lower courts always respect. Since punitive damages are still a new phenomenon in Hungary, judges have been, up to now, almost free to determine the civil law punishment of the author of the unlawful act. In Hungary, there is no cap on punitive damages, unlike in many (but not all) USA member states. In the USA, there is an increasing number of states legislating a cap on punitive damages. For instance, in Texas, punitive damages cannot exceed two times the sum of economic damages plus one time the sum of non-economic damages. If there are no compensatory damages, punitive damages cannot exceed 200000 USD. In the USA, the due process clauses in the Fifth and Fourteenth Amendments to the Constitution are often cited as sources of law making it necessary to put a cap to punitive damages. This is by and large a matter of substantive due process. Nowadays, the principle of substantive due process is experiencing a Renaissance in Hungarian law, making imitation of the American legal reasoning possible. In Hungarian jurisprudence, indemnity for non-economic damage, augmented by the punitive factor, could be astronomical, although, this is not the case. Hungarian courts tend to avoid disproportionate punitive damages. This was not so in the USA before the introduction of caps, which deterred Ger-

${ }^{3}$ B.W. Janke, F.X. Licari, Enforcing punitive damage awards in France after Fountaine Pajot, American Journal of Comparative Law, 3/2012, 775-804.

${ }^{4}$ S.P. Calandrillo, Penalizing punitive damages: why the Supreme Court needs a lesson in law and economics, George Washington Law Review, 4/2010, 774-821. 
man, Spanish and most other European legislators from introducing punitive damages into their national civil law. Nevertheless, there has always been some punitive factor in these European countries' indemnity systems. This punitive factor has never been recognized as punitive damages. It has been called the liberty of the judge to assess the amount of damages. In continental European countries, punishment is the task of public law; however, it seems unavoidable that civil law judges may punish the violator of the person's rights somewhat. This latent jurisprudence led Hungarian legislators to make this phenomenon legal and visible. Hungarian law may thus serve as an area of legal experimentation for Germany, Spain and other countries. If the Hungarian kind of punitive damages functions properly, it may open the door to legalize punishment under civil law in other countries alike. We have to wait years (maybe decades) until a solid Hungarian case law is developed in this field.

In 2018, Hoversten pointed out that: 'Modern American punitive damages serve not to compensate the plaintiff but to punish the defendant on behalf of the whole community. Therefore, when courts rely on foreign substantive law to impose punitive damages, they arguably violate the well-established principle that no court applies the penal laws of another sovereign. ${ }^{5}$ Considering the penal conception of punitive damages, it should be noted that, in the Hungarian legal system, punitive damages must not be awarded in an adhesive procedure because punitive damages are based neither on damage nor on loss pecuniarily assessed in the preceding criminal procedure. A civil procedure is to be initiated by the victim, if punitive damages are also requested.

Punitive damages serve a double preventive function:

- to prevent the author of the damage from reiterating their unlawful act, and

- to prevent other people from the imitation of the unlawful act.

This double preventive function is rooted in criminal prevention and restores the original function of delictual liability. Delictum not only concerns causing damage; it is also a matter of how the unlawful act was committed. The level of culpability (from negligence to intention) is also to be taken into consideration by the court. This return to the original functioning of delictual liability provides a legal instrument for the courts when, besides restorative justice, a social and judicial need for retributive justice also arises.

The emerging need for punitive damages does not necessitate a thorough change in the national legal system. The immanence of the legal institution of punitive damages in the indemnity system is not truly something new. In Hungarian law, punitive damages are largely applied when a patient's right to health is violated; to the extent that even in those cases in which neither economic nor

\footnotetext{
${ }^{5}$ P.A. Hoversten, Punishment but not a penalty? Punitive damages are impermissible under foreign substantive law, Michigan Law Review, 5/2018, 759-784.
} 
non-economic damage arises. However, Hungarian courts tend to apply the principle of de minimis non curat praetor, when the violation of the patient's right to health neither caused damage nor was in any way detrimental to the patient. The aim is to eliminate cases in which patients merely aim to obtain money, although, they have suffered no palpable injustice.

The no-fault systems of Sweden, Denmark and New Zealand stress the compensatory function of the damages and neglect punitive damages. In this wellfunctioning way of considering medical malpractice, the first aim is to compensate the injured patient. It is not important to punish the healthcare provider because the no-fault system is, most of all, in favour of restorative justice and not retributive justice. In this no-fault system, there is an avoidability standard instead of negligence standard. The avoidability standard means that the patient would not have suffered injury if the best practitioner had provided the healthcare. ${ }^{6}$ According to a recent article published in Health Policy, the health expenditures were reduced by $0.11 \%$ per capita in OECD countries with a no-fault system when deterrence and compensation were decoupled. However, OECD countries with a no-fault system but without decoupling deterrence and compensation had higher health expenditures. ${ }^{7}$ In 2012, Australian authors, inspired by the possible introduction of a no-fault system, analysed this type of medical malpractice system and found that it is fairer, quicker and less costly and that it ensures patient safety. ${ }^{8}$ In her article published in the Tort Law Review, Popa also proposed the introduction of a New Zealand type of no-fault system into Australian medical law. ${ }^{9}$ In New Zealand, the no-fault system had already been introduced in 2005, and, in the first four years, $83 \%$ percent of the claims concerning primary care treatment injuries were minor ones. ${ }^{10}$ An overwhelming number of minor claims that are almost automatically accepted are in favour of the patients, but, in the long run, it might be detrimental to the health law system. On the one hand, it is true that patient safety should be paramount, but, on the other hand, no money should be spent on frivolous claims. I believe that there is a positive side-effect of the negligence standard which should be sustained. Since only a small number of countries can afford a no-fault system, medical malpractice will long remain based on the standard of medical negligence in the majority of the world's legal systems.

${ }^{6}$ A.B. Kachalia, M.M. Mello, T.A. Brennan et al, Beyond negligence: avoidability and medical injury compensation, Social Science \& Medicine, 2/2008, 387-402.

7 T. Vandersteegen, W. Marneffe, I. Cleemput et al., The impact of no-fault compensation on healthcare expenditures: an empirical study of OECD countries, Health Policy, 3/2015, 367-374.

${ }^{8}$ D. Weisbrot, K.J. Breen, A no-fault compensation system for medical injury is long overdue, Medical Journal of Australia, 5/2012, 296-298.

${ }^{9}$ T. Popa, Practitioner perspectives on continuing legal challenges in mental harm and medical negligence: Time for a no-fault approach? Tort Law Review, 1/2017, 19-36.

${ }^{10} \mathrm{~K}$. Wallis, S. Dovey, No-fault compensation for treatment injury in New-Zealand, $B M J$ Quality \& Safety, 7/2011, 587-591. 
In most countries, there is no medical liability without negligence. The mere breach of the duty of care, if not done at least negligently, is not sufficient to establish the liability of the healthcare provider.

\section{CRIMINAL MEDICAL NEGLIGENCE}

In a criminal law case, negligence must be proven by the prosecutor, while, in a civil law case, negligence is presumed and it is the healthcare provider who must prove the lack of it (exculpation). Negligence in criminal law is based on what was expected of the accused physician, while negligence in civil law is based on a standard level that could have been reached by other physicians. Criminal law negligence (mens rea) is not presumed: besides the guilty act, mens rea must also be proven by the prosecutor. For example, criminal liability for gross negligence manslaughter can be established on condition that the prosecutor proves the gross negligence of the physician.

In the UK in 2015, Dr Bawa-Garba was sentenced for gross negligence manslaughter because a six-year-old child had died partly due to the doctor's medical negligence. Since understaffing that day played a huge role in the death of the child, many physicians and lawyers found the judgment unjust. In 2019, Samanta et al. saw this as a criminalisation of the doctor and placed the blame on a system failure. ${ }^{11}$ When it comes to criminal negligence, the fact that it was not solely the physician's negligence that led to the death of the patient usually excludes the establishment of the physician's criminal liability. In contrast with civil law negligence, when the contribution of the doctor's negligence to the death of the patient founds a certain degree of civil liability on the part of the doctor (or that of the vicariously liable hospital), the criminal liability of the doctor should be established on condition that the death was undoubtedly the result of the doctor's act or omission. In the case of criminal negligence, the hospital cannot be held vicariously liable.

In 2006, Quick has already been of the opinion that the legal institution of gross negligence manslaughter should not be applied to physicians for lack of an objective and fair measurement. ${ }^{12}$

Negligence under civil law is the playground of lawyers. A good lawyer would do anything to prove that the defendant healthcare provider was not even negligent when breaching the duty of care. Since breach of duty is usually indisputable, that is the main task of the healthcare provider's lawyer.

${ }^{11}$ A. Samanta, J. Samanta, Gross negligence manslaughter and doctors: ethical concerns following the case of Dr Bawa-Garba, Journal of Medical Ethics, 1/2019, 10-14.

${ }^{12}$ O. Quick, Prosecuting 'gross' medical negligence: manslaughter, discretion, and the crown prosecution service, Journal of Law and Society, 3/2006, 421-450. 
The difference in the burden of proof can be explained by criminal law as a means of punishment and by the civil law as a means of compensation. When, for example, in the case of gross negligence, besides compensatory damages, it also comes to punitive damages, the punitive factor is dependent on whether aggravated negligence on the part of the physician can be proven. In the case of punitive damages, it is the plaintiff's task to prove that the physician's negligence was gross. The aggravated character of medical negligence is not presumed.

\section{FROM NEGLIGENCE TO INTENTION}

Medical negligence supposes that the healthcare provider does not intend to cause injury to the patient, although, the possibility that a physician or a nurse practitioner has intentionally or knowingly harmed the patient cannot be excluded. Injuring the patient voluntarily is both legally and ethically unforgivable. The healthcare provider's task is to help and protect the patient, so voluntarily injuring the patient is seriously punishable not only under criminal law but also under civil law. The possible voluntary way of committing medical malpractice is rare, although, from time to time, it occurs. When malpractice is committed voluntarily, the case is first of all tried before criminal court, and then comes the assessment of the civil liability. When medical malpractice is literally caused by negligence, criminal liability is rarely established: the case is rather about compensatory and punitive damages. When health damage is caused by gross negligence, punitive damages are usually higher than in the case of average medical negligence.

Malpractice cases are brought before a criminal court when there is no other way to prevent the medical or nurse practitioner from repeating their guilty act. An extrajudicial settlement between patient and healthcare provider is often applied. Within the framework of criminal law mediation, the patient obtains money in exchange for not initiating a criminal procedure against the physician. Civil law mediation is a possible way to avoid an expensive, lengthy and otherwise undesired civil procedure. In Hungary, in serious cases of voluntarily injuring the patient, criminal law mediation is not permitted by law.

\section{MEDICO-LEGAL PRESUMPTIONS}

It is rooted in the history of Hungarian medical law that patients must only prove that their health damage came about within a doctor-patient relationship. The mere fact that there was a treatment relationship between physician and patient presupposes that the health damage was caused by the treating doctor. Unlike generally, if the physician's lawyer cannot produce proof (e.g. healthcare 
documentation), Hungarian courts tend to presume that the treating physician caused the health damage to the patient. This rebuttable presumption, fortified by the lack of proper healthcare documentation to the detriment of the physician, already existed in the Hungarian justice system in the second half of the nineteenth century, and it has not been changed since. The physician is presumed to have been culpable when causing damage to the patient, though this presumption can be rebutted. The burden of proof is on the physician. So the liability of physicians with regard to patients is sufficiently objective to serve the best interests of the patients, whose defense is otherwise weak. These legal presumptions are historical ones in Hungarian medical law, and they have survived all the changes of the Hungarian legal system. These historical legal presumptions testify to the fact that, by and large, Hungarian medical civil law has not changed in essence for more than a century. It is important to examine the history of Hungarian medical law in depth to find the roots of the administration of justice with regard to medical law. Without an adequate examination of the medico-legal history, including case law from before the Second World War, the functioning of medical law would not be understandable. Thus, we can see the differences and similarities in present-day legislative processes, and judges as well as lawyers can interpret the old-new medical law with a view to preserving good old legal practice. Similarly to the 'gutes altes Recht' in the German legal culture, the 'good old legal practice' also has a place in the science of legal history. An analysis of legal practice, made possible courtesy of the Hungarian national archives, occupies an increasingly important place in the interpretation and perception of ancient legal norms. Good old law and good old legal practice are mutually inseparable, even in countries where statute law predominates over case law. The dichotomy of statute law and case law starts to lose its importance because statute law correlates with case law, and this correlation ensures legal certainty. In addition to the laws themselves, lawyers have always had the task of knowing judicial practice in depth, and it is knowledge of judicial practice that has made ancient and present-day lawyers useful in the eyes of their clients.

The evolution of Hungarian medical law is concomitant with the evolution of other European types of medical laws. English medical law differs greatly from continental medical law, though English medical law has conveyed many legal principles and legal interpretations to continental medical laws. For instance, the Bolam test (1957) in English medical law ${ }^{13}$ is very similar to the Hungarian 'standard of a responsible body of medical opinion'. All in all, the physician is not considered as having been negligent when causing health damage to the patient if other professionals in the same area of medicine testify in court that they would have acted similarly in a similar situation. This standard sets up a special medical

${ }^{13}$ Bolam $v$ Friern Hospital Management Committee. [1957] 1 WLR 582. 
level of culpability for physicians, making the exculpation of the physician difficult, but not impossible. It is interesting to see that the institution of English common law noted above resembles a legal institution under Section 77(3) of Hungarian Act CLIV of 1997 on Health. It is not a unique case in both English and Hungarian law. English common law contains a number of legal institutions that fall under statute law on the continent.

\section{THE RIGHT TO A CHEAP JUDICIAL PROCEDURE}

Studdert et al. already stated in 2006 in The New England Journal of Medicine that, in the USA, many patients who have suffered injury due to medical negligence do not bring the case to court. Studdert et al. believe that a great deal of money has been spent on 'frivolous claims'. ${ }^{14}$ This is true not only in the USA, but also in other countries, including Hungary.

This fact suggests that something is off with the judicial practice in the field of medical negligence. Insurance companies pay a great deal to patients who have time and money to finance a lawsuit, while justice is not served in cases of the less well-off. They remain trapped by the high costs of a civil procedure. In Hungary, according to recent court practice, medical experts' opinions given in a criminal procedure may be taken into consideration in a civil procedure that may follow, which results in a growing number of medical negligence cases started before a criminal court, then followed by a civil procedure. Thus, patients can save money because they do not have to pay for the expert opinion.

Legal procedures are costly, so, in countries where there is a gulf between the rich and the poor, the malfunctioning of the judicial system deters the poor from medical negligence claims, which further enlarges this gulf. Thus, not always, but many times, instead of righteous medical negligence claims, questionable medical negligence cases are tried before court, which does not serve the spirit of the 'rule of law'.

In order to make Article 14 of the International Covenant on Civil and Political Rights a reality, the right to a cheap judicial process ought to be ensured for all. A cheap judicial process is a basic need of all states and societies abiding by the rule of law. The social equilibrium must be maintained not only when legislating but also when applying the enacted laws.

A cheap judicial process should not be tantamount to a legal process of lower quality. A cheap judicial process is acceptable on condition that the quality of the legal practice does not drop.

${ }^{14}$ D.M. Studdert, M.M. Mello, A.A. Gawande et al., Claims, errors, and compensation payments in medical malpractice litigation, The New England Journal of Medicine, 2006, 354, 2024-2033. 
In the USA, as well as in many EU member states, law firms, specialised in medical malpractice lawsuits, make use of advertising on the web and even on hoardings located near hospitals. ${ }^{15}$ This advertising practice seems strange from the aspect of Eastern Central European countries, such as Hungary, because, in those countries, law firms rather tend to attract plaintiffs in a more subtle way: e.g. through business and family relationships. In Hungary, patients usually turn to the lawyer proposed by a family member or by a colleague. Law firms also exist in Hungary, but a practice of direct advertising is alien to them; this would rather scare away potential plaintiffs than attract them. However, law firms in Hungary also reach injured patients through the web.

A Western type of medical malpractice advertising might be a step towards a cheap judicial process, if law firms competed with each other in offering their services at a lower price. A cheap judicial process is in the interests of not only the plaintiffs, but also of the law firms. Lowering procedural costs would bring more clients to an increasing number of law firms, which would enable the less well-off to bring their medical malpractice cases before the courts.

\section{HUMAN LIFE, AS A VALUE, PREVAILS OVER MEDICAL NEGLIGENCE CLAIMS}

After astronomical damages have been awarded to plaintiffs for wrongful lives, there is a tendency from the USA to Europe to view 'the utter void of nonexistence' as worse than a life with defects. Nowadays, even in Hungary, most wrongful life claims are rejected. That is, the child who has to live with serious health disadvantages due to medical negligence is not entitled to damages. (See civil uniformity decision No. 1/2008 PJE made by the Supreme Court of Hungary!) A new tendency of ruling against wrongful birth claims has also appeared. That is, a mother whose baby's health is damaged during delivery might face a judgment against her claim for damages. In Hungary, according to the decision on principle No. EBH 2015.P.11 issued by the Supreme Court of Hungary, wrongful birth claims made by the parents are accepted by the courts, and some dissenting judgments still occur which also award damages for wrongful life. As Nelson concluded in the Alberta Law Review in 2016, the Canadian jurisprudence also tends to reject wrongful life claims; however, they do not clarify that the problem is that no damages should be awarded to infant plaintiffs for wrongful life. Instead, recent Canadian judgments in this area are based on such justifications as the lack of negligence, etc. ${ }^{16}$ The national court practice in this area of law seems uncertain

${ }^{15}$ C.W. Ghobadi, O. Gevorgyan, C.E. Bednarski et al., Medical malpractice web advertising, Issues in Law \& Medicine, 2/2017, 205-212.

${ }^{16}$ E.L. Nelson, Prenatal harm and the duty of care, Alberta Law Review, 4/2016, 933-953. 
all over the world, thus leaving behind legal uncertainty. Wrongful conception claims are also disputed on ethical and religious grounds. The main rationale is that life cannot be seen as damage.

I believe that wrongful conception, wrongful birth and wrongful life claims constitute partly a legal, partly an ethical problem. From a legal aspect, an economic approach is emphasized. That is, huge damages paid for wrongful life run counter to the interests of both the healthcare provider and the insurance company. The ethical aspect largely involves religious grounds. Axiological plurality requires that the values of those with a different opinion are also to be respected.

In Hungarian law, for example, a child's right to life prevails over a mother's right to die. That is, the mother does not have the right to refuse life-sustaining medical interventions when pregnant and able to give birth to a child. This legal rule, implied in the Hungarian Act on Health, underlines that life, as a value, is paramount. That is, neither the mother's interests in dying nor the child's interests in not being born should predominate over life. When this ethical rule, which is put into a legal rule, is not misused, the predominance of life as a value is acceptable. It is up to medical practice and court practice to properly apply the right to life, particularly when this right runs counter to differing interests.

Usually, medical negligence claims are not viable when the medical activity aims to save the patient's life. In Hungary, the court practice tends to reject a claim for damages when the health damage is caused to save a patient's life. After having survived a near-death situation, there are patients who file a lawsuit against the healthcare provider because of the secondary health damage they have suffered. For example, the patient has to live with an ugly cicatrice that causes discomfort, so the patient claims compensation. It is, of course, not only the Hungarian legal practice that looks on this sort of health damage as lawfully caused. In a near-death situation, the patient's consent to secondary health damage is presumed by the physician and, in most cases, this presumption cannot be rebutted later, in a civil procedure.

\section{DO NON-PAYING PATIENTS HAVE THE SAME RIGHTS VIS-À-VIS HEALTHCARE PROVIDERS AS THEIR PAYING COUNTERPARTS?}

The human rights to life and health are enshrined in the Universal Declaration of Human Rights (UNO, 1948). The right to life falls under Article 3, while the right to health is set down in Article 25. The right to health includes the right to medical care. The right to health of the patient is a right that must be respected by all other people, so no money can be asked from the patient in exchange. This does not mean that the right to medical care is free. Demanding payment from the patient does not run counter to the human rights of the patient. When the patient 
pays for medical care, the patient also buys patient's rights vis-à-vis the healthcare provider. In exchange for payment, the patient has the right to demand compensatory and punitive damages if the healthcare provider does not reach the appropriate standard of care.

All in all, by making the right to medical care onerous, it is not just the patient who obtains rights, but obligations are also inflicted on the healthcare provider.

Considering the cases of Mehmet Sentürk and Bekir Sentürk $v$ Turkey (2013) and Asiye Genc $v$ Turkey $(2015)^{17}$, the European Court of Human Rights regarded the lack of a legal guarantee to access to healthcare in emergency situations as a violation of the right to life (Article 2 of the European Convention on Human Rights). Refusing medical care to poor patients in emergency situations is not only against the human right to health, but it might be contrary to the human right to life. ${ }^{18}$ From the aspect of these decisions made by the European Court of Human Rights, the right to health and the right to life coincide. When there is such a coincidence, the right to life overrides the onerous character of the right to medical care, thus making the right to medical care free for even those who cannot pay. The question arises whether poor patients enjoying free medical care have the same rights vis-à-vis healthcare providers as patients who pay for the medical service. I believe that poor patients should have the same rights vis-à-vis healthcare providers and that healthcare providers should have the same obligations vis-à-vis non-paying patients as in case of purchased healthcare services. The social gap filled by the extension of the human right to medical care establishes civil and criminal liabilities in doctor-patient relationships. In a possible medical negligence case, lawsuits involving non-paying poor patients should be considered equally.

In legal practice, it is not permissible to discriminate against the poor; however, in countries with little rule of law, the lawful interests of the poor might be disregarded when colliding with the interests of the better-off. The quality of the rule of law is largely based on those who are entitled to ensure it. Medical negligence cases constitute a field of legal practice that reliably indicates the local level of the rule of law.

In 2017, Castillo et al. wrote as follows: 'Faced with the persistence of huge global health inequalities, the WHO began to reshape itself, leaving behind the notion of health as a human right and imposing the challenge of reducing the wide gap that separates international intergovernmental laws from reality.' 19

${ }^{17}$ Mehmet Şentürk and Bekir Şentürkv Turkey (Application No. 13423/09) (2013) 60 EHRR 4; Asiye Genç v Turquie (Application No. 24109/07), Judgment of 27 January 2015.

${ }^{18}$ A. Nissen, A right to access to emergency healthcare: the European Court of Human Rights pushes the envelope, Medical Law Review, 4/2018, 693-702.

${ }^{19}$ C.H.M. Castillo, V. Garaffa, T. Cunha et al., Access to healthcare as a human right in international policy: critical reflections and contemporary challenges, Ciencia \& Saude Coletiva, 7/2017, 2151-2160. 
A human rights approach to medical negligence is not adopted by all national courts. For example, in Hungary, the human rights to life and health rarely appear in medical negligence cases. Hungarian judges apply civil law instruments, with only a very small number of lawyers citing human rights in medical negligence litigation. This does not necessarily signal a lack of respect for human rights on the part of the national courts. In Hungary, the courts are simply not used to interpreting a medical negligence case by means of human rights because their attention is on the technical aspect of law. However, the rights to life and health are expressed as a person's right by Section 2:43(a) of the Hungarian Civil Code in effect.

\section{UNMEASURABLE FACTORS IN MEDICAL NEGLIGENCE CASES}

Medical negligence cases reflect the present general judicial opinion in this area of law. The law made by judges may ameliorate the local quality of the rule of law, although, judges are not lawmakers. Legislative power is to be separated from judicial power. Judges enjoy the right merely to correct statutes, but never to challenge the original aim and meaning of the text of laws. With due respect to this restriction, the judges possess enormous power socially and economically to reshape the legal environment tied to a socio-economic issue. Medical negligence is a legal topic which is of great significance socio-economically and which concerns a whole society made up of patients and future patients. The judge-made law fills a legal hiatus when interpreting medical law in a case that does not fully fit the rules of the related positive law. When doing so, judges fulfil their task to serve justice; however, this justice is composed of the personal belief of the judge, the ratio decidendi of previous judgments in this field and the general opinion expressed by the majority of the local society. These three elements are, also occasionally, amended by various factors, but no legal interpretation is possible without regard to these three basic elements.

Empathy is not statistically measurable; however, a judge's empathy for a patient, who has been a victim of a medical negligence, is widely expected. Without entering into psycho-legal research, it seems broadly understandable that the empathetic character of a judge has a huge impact on the outcome of a lawsuit. This empathy is not necessarily for the patient; in many civil law cases, the physicians find themselves exposed to patients seeking money, or, in criminal law cases, to vengeful patients and relatives. Westaby and Jones argue that empathy plays a large role in making legal practice more effective and the appreciation of ethics and values deeper. ${ }^{20} \mathrm{~A}$ physician's empathy for a patient has a huge role in

${ }^{20}$ C. Westaby, E. Jones, Empathy: an essential element of legal practice or 'never the twain shall meet'? International Journal of the Legal Profession, 1/2018, 107-124. 
avoiding further legal procedures. Many patients, who have suffered medical negligence caused by an otherwise empathetic and polite physician, refrain from lawsuits. This phenomenon may be explained by the legal effect of the mere behaviour of the physician. In contrast, a medical negligence case of little relevance is usually brought to court when the physician behaves impolitely and without empathy. These unmeasurable psycho-legal effects have played an important role in the development of medical negligence case law today.

Unmeasurable factors, such as the behaviour of the medical practitioner towards the patient, have been scrutinized by legal scholars and psychologists in the last few years. It seems clear that the physician's manners count a great deal when it comes to a medical negligence case. Only a small proportion of injured patients insist on suing the vicariously liable hospital when the treating physician has been morally upright. This moral and behavioural correctness can save money for the hospital (and for the insurer). If we compare two healthcare providers, the more attention is paid to the moral and behavioural formation of the physicians and nurses, the fewer damages are to be paid, even if medical negligence occurs in a very similar number in both places.

\section{INFORMATION AND MEDICAL NEGLIGENCE}

A current issue in the area of medical negligence is whether to inform the patient and their relatives or not. According to English law, when the patient's relatives are exposed to a danger posed by the patient's disease, the relatives are to be informed about that danger. The omission of giving information constitutes a breach of duty and thus leads to medical negligence. This is not necessarily the case in Hungary. There health data protection is paramount, and, in most cases, relatives are not entitled to know about the patient's disease. A rarely applied exception is stipulated by Section 7(5) of Act XLVII of 1997 on Health Data Protection, making it possible to request a patient's health data to diagnose a family member's health problem. There are further exceptions when a patient's health data may be conveyed to the authorities. All that is in full accordance with Article 9 of the GDPR. Di Iorio et al. argued in the Journal of Medical Ethics in 2014 that the right to privacy overrides the right to health in Europe. ${ }^{21}$ This theoretical problem has always existed and has led to a medical practice sometimes in contrast with the written law. When it comes to a patient who poses an imminent risk to their relatives, it is common medical practice to inform the relatives in order to protect them. Otherwise, divulging the patient's health data constitutes a breach

${ }^{21}$ C.T. Di Iorio, F. Carinci, J. Oderkirk, Health research and system's governance are at risk: Should the right to data protection override health? Journal of Medical Ethics, 7/2014, 488-492. 
of the patient's right to health data protection (Section 2:43(e) of the Hungarian Civil Code). Health data are sensitive, and a growing number of medical negligence cases are factually based on a breach of data protection. This is a sign of increasing legal knowledge among patients and also that of the activity of lawyers in the area of medical negligence. Even if a breach of health data protection usually leads to theoretical legal debates, the outcomes of these lawsuits are tangible: damages are paid to the claimant. In Hungary, lawsuits based on a breach of the patient's right to health data protection have recently gained in importance. Previously, the legal institution of medical negligence was preserved for what are seen as more serious legal problems. In practice, the extension of the notion of medical negligence to not only imply cases of bodily harm is a step toward integrating Hungary into the Western European legal culture.

All in all, the Hungarian legal system tends toward protection of the patient's health data, while English law rather supports protection of the patient's relatives. There are pros and cons of both legal tendencies. Health data protection is within a person's rights, which should be respected by all. Only exceptional cases exist that allow the physician to breach that person's right. It is true that a patient's unalienable rights include not only their bodily integrity, but also their sensitive data.

This problem may also be contemplated from another aspect. When it comes to obtaining informed consent of the patient, the patient is supposed to have all necessary information at their disposal to make a decision whether to consent to a medical intervention. However, according to the ratio decidendi of the Sidaway case, there are some rare side-effects about which the physician is not obliged to inform the patient, especially when they occur in less than $1 \%$ of cases..$^{22}$ The recent Montgomery case stated that the patient should be told what they want to know and not what the physician thinks is important. ${ }^{23}$

In Hungary, as in all democratic countries, the patient has the right to give their consent to a medical intervention or not, and, similarly to English law, the patient need not be informed about unlikely side-effects. If a side-effect eventually occurs, the patient usually achieves nothing in suing the healthcare provider. According to Hungarian medical practice, the informed consent is provided in writing, but patients often sign a declaration of consent after receiving no more than a short verbal briefing. In Hungary, the declaration of consent signed by the patient usually contains a long list of possible negative outcomes, and the patient only faces what was in it when bringing the medical negligence case before court.

The patient is entitled to information about their state of health, and the information may only be withheld when it is in the best interests of a psychiatric patient (Section 193 of Act on Health of Hungary). There was a practice during the

\footnotetext{
${ }^{22}$ Sidaway $v$ Board of Governors of the Bethlem Royal Hospital [1985] AC 871

${ }^{23}$ Montgomery $v$ Lanarkshire Health Board [2015] SC 11 [2015] 1 AC 1430
} 
years of communism in Hungary of not informing the patient of a serious diagnosis in order to spare them (pia fraus). This paternalistic approach led to an abuse:

- the patient did not have sufficient time to arrange their affairs before exiting;

- the relatives and authorities were better informed than the patient, a situation which was detrimental to the patient's rights;

- instead of considering the patient as someone with rights and obligations like anyone else, they were exposed to possible pity on the part of the physicians and nurses;

- in the case of medical negligence, the patient had no knowledge of the information required to seek a potential legal remedy.

\section{DIVERSITY AND UNIFORMITY IN THE MEDICAL NEGLIGENCE LAW}

New tendencies in medical negligence concern not only Hungary, but all market democracies. These new tendencies are reflected in jurisprudence; however, legislative processes also mirror the social and economic needs of the population. The well-functioning old tendencies in medical negligence should be sustained and new tendencies, which do not conflict the right path of legal development, should also occupy their place in local legal systems.

On the one hand, it is important to attempt to make the legal practice with regard to medical negligence as uniform as possible in all countries because this would lead to a legal certainty not only at the national level, but also when it comes to transboundary legal cases. On the other hand, the national characteristics of medical negligence cases are part of local legal cultures. To a certain degree, legal cultural diversity is a universal value. This universal value and the need for legal uniformity should thus be balanced.

\section{REFERENCES}

R.B. Brown, Canada's first malpractice crisis: medical negligence in the late nineteenth century, Osgoode Hall Law Journal, 3/2017, 777-804.

L. Berlin, Medical errors, malpractice, and defensive medicine: an ill-fated triad, Diagnosis, 3/2017, 133-139.

B.W. Janke, F.X. Licari, Enforcing punitive damage awards in France after Fountaine Pajot, American Journal of Comparative Law, 3/2012, 775-804.

S.P. Calandrillo, Penalizing punitive damages: why the Supreme Court needs a lesson in law and economics, George Washington Law Review, 4/2010, 774-821.

P.A. Hoversten, Punishment but not a penalty? Punitive damages are impermissible under foreign substantive law, Michigan Law Review, 5/2018, 759-784. 
A.B. Kachalia, M.M. Mello, T.A. Brennan et al, Beyond negligence: avoidability and medical injury compensation, Social Science \& Medicine, 2/2008, 387-402.

T. Vandersteegen, W. Marneffe, I. Cleemput et al., The impact of no-fault compensation on healthcare expenditures: an empirical study of OECD countries, Health Policy, 3/2015, 367-374.

D. Weisbrot, K.J. Breen, A no-fault compensation system for medical injury is long overdue, Medical Journal of Australia, 5/2012, 296-298.

T. Popa, Practitioner perspectives on continuing legal challenges in mental harm and medical negligence: Time for a no-fault approach? Tort Law Review, 1/2017, 19-36.

K. Wallis, S. Dovey, No-fault compensation for treatment injury in New-Zealand, BMJ Quality \& Safety, 7/2011, 587-591.

A. Samanta, J. Samanta, Gross negligence manslaughter and doctors: ethical concerns following the case of Dr Bawa-Garba, Journal of Medical Ethics, 1/2019, 10-14.

O. Quick, Prosecuting 'gross' medical negligence: manslaughter, discretion, and the crown prosecution service, Journal of Law and Society, 3/2006, 421-450.

Bolam v Friern Hospital Management Committee. [1957] 1 WLR 582.

D.M. Studdert, M.M. Mello, A.A. Gawande et al., Claims, errors, and compensation payments in medical malpractice litigation, The New England Journal of Medicine, 2006, 354, 2024-2033.

C.W. Ghobadi, O. Gevorgyan, C.E. Bednarski et al., Medical malpractice web advertising, Issues in Law \& Medicine, 2/2017, 205-212.

E.L. Nelson, Prenatal harm and the duty of care, Alberta Law Review, 4/2016, 933-953.

Mehmet Şentürk and Bekir Şentürk v Turkey (Application No. 13423/09) (2013) 60 EHRR 4; Asiye Gençv Turquie (Application No. 24109/07), Judgment of 27 January 2015.

A. Nissen, A right to access to emergency healthcare: the European Court of Human Rights pushes the envelope, Medical Law Review, 4/2018, 693-702.

C.H.M. Castillo, V. Garaffa, T. Cunha et al., Access to healthcare as a human right in international policy: critical reflections and contemporary challenges, Ciencia \& Saude Coletiva, 7/2017, 2151-2160.

C. Westaby, E. Jones, Empathy: an essential element of legal practice or 'never the twain shall meet'? International Journal of the Legal Profession, 1/2018, 107-124.

C.T. Di Iorio, F. Carinci, J. Oderkirk, Health research and system's governance are at risk: Should the right to data protection override health? Journal of Medical Ethics, 7/2014, 488-492.

Sidaway $v$ Board of Governors of the Bethlem Royal Hospital [1985] AC 871

Montgomery $v$ Lanarkshire Health Board [2015] SC 11 [2015] 1 AC 1430 
Dr Mate J. Jules, naučni istraživač

Univerzitet $u$ Segedinu

Medicinski fakultet

Institut za sudsku medicinu

mate.julesz@freemail.hu

\section{Tendencije u oblasti nepažnje medicinskog osoblja, sa posebnim osvrtom na Mađarsku}

Sažetak: Nepažnja medicinskog osoblja već je dugo u fokusu pravnih istraživanja u većini zemalja. U nekim zemljama standard nepažnje zamenjen je avoidability standardom, koji vodi ka sistemu odgovornosti bez obzira na krivicu (no-fault system). Ipak, većina pravnih sistema primenjuje standard nepažnje. Prema mom shvatanju, standard nepažnje treba da se održi jer, uprkos nesumnjivim prednostima no-fault sistema, ,,dobri stari zakon“ o nepažnji medicinskog osoblja promoviše veću pravnu sigurnost i bezbednost pacijenata. Pojam nepažnje medicinskog osoblja u oblasti krivičnog prava razlikuje se od pojma nepažnje medicinskog osoblja u oblasti građanskog prava kako u pogledu tereta dokazivanja, tako i u drugim aspektima. U Velikoj Britaniji, mnogi pravnici i lekari protestuju protiv pravne prakse ubistva usled grube nepažnje, što bi moglo da služi kao primer drugim zemljama. Uvećini zemalja kontinentalne Evrope, izvršenje strane presude kojom se dosuđuje naknada štete koja ima kaznenu funkciju bilo bi u suprotnosti s javnim poretkom; međutim, u nekim zemljama, poput Francuske i Mađarske, ovakva presuda se može izvršiti.

Ključne reči: pojam nepažnje medicinskog osoblja u oblasti građanskog prava, Mađarska, naknada štete koja ima za cilj kažnjavanje štetnika, naknada koja ima za cilj otklanjanje štetnih posledica, pojam nepažnje medicinskog osoblja u oblasti krivičnog prava, pravo na jeftin sudski postupak.

Datum prijema rada: 06.03.2019. 